\title{
Integrating spot short-term measurements of carbon emissions and backward dietary energy partition calculations to estimate intake in lactating dairy cows fed ad libitum or restricted
}

\author{
A. B. D. Pereira, ${ }^{*}$ S. A. Utsumi, † C. D. Dorich, $\ddagger$ and A. F. Brito*1 \\ *Department of Biological Sciences, University of New Hampshire, Durham 03824 \\ †Kellogg Biological Station, Michigan State University, Hickory Corners 49060 \\ fInstitute for the Study of Earth, Oceans, and Space, University of New Hampshire, Durham 03824
}

\begin{abstract}
The objective of this study was to use spot shortterm measurements of $\mathrm{CH}_{4}\left(Q \mathrm{CH}_{4}\right)$ and $\mathrm{CO}_{2}\left(Q \mathrm{CO}_{2}\right)$ integrated with backward dietary energy partition calculations to estimate dry matter intake (DMI) in lactating dairy cows. Twelve multiparous cows averaging $173 \pm 37 \mathrm{~d}$ in milk and 4 primiparous cows averaging $179 \pm 27 \mathrm{~d}$ in milk were blocked by days in milk, parity, and DMI (as a percentage of body weight) and, within each block, randomly assigned to 1 of 2 treatments: ad libitum intake (AL) or restricted intake (RI $=90 \%$ DMI $)$ according to a crossover design. Each experimental period lasted $22 \mathrm{~d}$ with $14 \mathrm{~d}$ for treatments adaptation and $8 \mathrm{~d}$ for data and sample collection. Diets contained (dry matter basis): $40 \%$ corn silage, $12 \%$ grass-legume haylage, and $48 \%$ concentrate. Spot short-term gas measurements were taken in 5-min sampling periods from 15 cows (1 cow refused sampling) using a portable, automated, open-circuit gas quantification system (GreenFeed, C-Lock Inc., Rapid City, SD) with intervals of $12 \mathrm{~h}$ between the 2 daily samples. Sampling points were advanced $2 \mathrm{~h}$ from a day to the next to yield 16 gas samples per cow over $8 \mathrm{~d}$ to account for diurnal variation in $Q \mathrm{CH}_{4}$ and $Q \mathrm{CO}_{2}$. The following equations were used sequentially to estimate DMI: $(1)$ heat production $(\mathrm{MJ} / \mathrm{d})=(4.96+16.07 \div$ respiratory quotient) $\times Q^{2} \mathrm{CO}_{2}$; respiratory quotient $=$ $0.95 ;(2)$ metabolizable energy intake $(\mathrm{MJ} / \mathrm{d})=$ (heat production + milk energy) \pm tissue energy balance; (3) digestible energy $(\mathrm{DE})$ intake $(\mathrm{MJ} / \mathrm{d})=$ metabolizable energy $+\mathrm{CH}_{4}$ energy + urinary energy; (4) gross energy $(\mathrm{GE})$ intake $(\mathrm{MJ} / \mathrm{d})=\mathrm{DE}+[(\mathrm{DE} \div$ in vitro true dry matter digestibility) - DE]; and (5) DMI $(\mathrm{kg} / \mathrm{d})=\mathrm{GE}$ intake estimated $\div$ diet GE concentration. Data were analyzed using the MIXED procedure of SAS (SAS Institute Inc., Cary, NC) and Fit Model procedure in
\end{abstract}

Received April 1, 2015.

Accepted August 28, 2015.

${ }^{1}$ Corresponding author: andre.brito@unh.edu
JMP $(\alpha=0.05$; SAS Institute Inc.). Cows significantly differed in DMI measured (23.8 vs. $22.4 \mathrm{~kg} / \mathrm{d}$ for AL and RI, respectively). Dry matter intake estimated using $Q \mathrm{CH}_{4}$ and $Q \mathrm{CO}_{2}$ coupled with dietary backward energy partition calculations (Equations 1 to 5 above) was highest in cows fed for AL (22.5 vs. $20.2 \mathrm{~kg} / \mathrm{d})$. The resulting $\mathrm{R}^{2}$ were 0.28 between DMI measured and DMI estimated by gaseous measurements, and 0.36 between DMI measured and DMI predicted by the National Research Council model (2001). Results showed that spot short-term measurements of $Q \mathrm{QH}_{4}$ and $\mathrm{QCO}_{2}$ coupled with dietary backward estimations of energy partition underestimated DMI by 7.8\%. However, the approach proposed herein was able to significantly discriminate differences in DMI between cows fed for AL or RI.

Key words: carbon emission, dairy cow, dry matter intake, GreenFeed

\section{INTRODUCTION}

Alternative noninvasive and nonrestrictive methods for accurate estimation of DMI in grazing animals are needed to advance pasture-based research. Herbage intake for grazing animals has been generally estimated by the following equation: fecal output $\div(1-$ diet digestibility). Although this equation is simple in principle, accurate determination of fecal output and nutrient digestibility for grazing animals is challenging. Fecal collection bags have been used to measure total fecal output in grazing animals (Sankhyan et al., 1999; Storeheier et al., 2003). However, this technique is laborious and may have limited application for large ruminants such as cattle because it can negatively affect grazing behavior (Mayes and Dove, 2000). An alternative approach is to use external and internal markers to estimate fecal output and diet digestibility, but marker methodology has its own set of limitations including cyclic changes in fecal marker concentration or poor recovery of markers in feces (Malossini et al., 1996; Dove, 2010). Although increasing the number of samples or animals could improve the accuracy of spot 
sampling techniques used for feces and urine (Malossini et al., 1996), they are not practical to be applied in commercial farming settings. In addition, several currently available equations exist [e.g., Agricultural and Food Research Council (1993); NRC (2001); Cornell Net Carbohydrate and Protein System (Fox et al., 2004; Tylutki et al., 2008)] that use empirical approaches to predict DMI with animal-related variables such as BW, milk yield and composition, and DIM entered as fixed effects in the models.

Energy requirements of dairy cows and relationships with DMI were examined extensively by indirect calorimetry experiments (Ferrell and Oltjen, 2008). The most common approach has been the use of individual or small groups of cows in enclosed chamber systems, which allows for precise measurements of utilization and excretion of energy using gaseous emissions (Blaxter and Clapperton, 1965). Alternative techniques to respiratory chambers are enabling scientists to collect or record gas measurements from cattle in their own production settings (e.g., grazing, free stall). Specific examples include quantifications of (1) heat production (HP) from $\mathrm{O}_{2}$ consumption per heartbeat (Brosh et al., 1998; Aharoni et al., 2006), (2) energy expenditure using the ${ }^{13} \mathrm{C}$ bicarbonate technique coupled with $\mathrm{O}_{2}$ consumption and respiratory quotient (RQ; Junghans et al., 2007; Kaufmann et al., 2011), (3) carbon emissions using tracer techniques (Stewart et al., 2008; Madsen et al., 2010), and (4) $\mathrm{CO}_{2}$ flux $\left(\mathbf{Q} \mathbf{C O}_{2}\right)$ and $\mathbf{C H}_{4}$ flux $\left(\mathbf{Q C H}_{4}\right)$ in animal breath (Branco et al., 2015; Dorich et al., 2015; Huhtanen et al., 2015).

A portable, automated, open-circuit gas quantification system (GQS; GreenFeed; C-Lock Inc., Rapid City, SD) has been used recently to obtain spot shortterm measurements of $Q \mathrm{CH}_{4}$ and $Q \mathrm{CO}_{2}$ in near realtime mode and with minimal disturbance to the natural behavior of the cow (Branco et al., 2015; Dorich et al., 2015; Huhtanen et al., 2015). Methane flux from lactating dairy cows housed in a poorly ventilated tiestall barn and measured with the GQS was less variable than $Q \mathrm{CH}_{4}$ measured with sulfur hexafluoride (Dorich et al., 2015). It is noteworthy that both the GQS and sulfur hexafluoride can sample a large number of animals particularly in outdoor settings (Hegarty, 2013). The GQS measured spot $Q \mathrm{CO}_{2}$ and $Q \mathrm{CH}_{4}$ with less variability than a nonflux spot sampling of emitted carbon in lactating dairy cows (Huhtanen et al., 2015). Compared with calorimetric chambers, the GQS yielded similar results of emitted carbon (Hammond et al., 2013). The objective of the current study was to use the GQS technique as a proof-of-concept methodology to estimate DMI and differences in intake levels in lactating dairy cows fed for ad libitum (AL) or restricted intake (RI). Specifically, we aimed to determine HP through spot short-term measurements of $Q^{-O_{2}}$ and couple $Q \mathrm{CO}_{2}$ and $Q \mathrm{CH}_{4}$ with backward dietary energy calculations to estimate gross energy (GE) intake and DMI (i.e., DMI-E). We then compared DMI-E with DMI measured (i.e., DMI-M), intake predictions from the NRC (i.e., DMI-NRC), and estimations from an empirical gas-based technique (i.e., DMI-CM; Casper and Mertens, 2010). Our future goal is to refine this methodology to estimate DMI from a large number of animals in pasture-based and other farm conditions (e.g., free stall, bedded pack barns). We hypothesized that $Q \mathrm{CH}_{4}$ and $Q \mathrm{CO}_{2}$ could be used as biomarkers for accurate estimation of DMI in lactating dairy cows when integrated with backward dietary energy partition calculations.

\section{MATERIALS AND METHODS}

\section{Experiment Date and Location}

The experiment was conducted from March 4 to April 18, 2013, at the University of New Hampshire Fairchild Dairy Teaching and Research Center (Durham, NH). Samples were processed at the Keener Dairy Research Building (Durham, NH). Care and handling of the animals was reviewed, approved, and conducted according to the University of New Hampshire Institutional Animal Care and Use Committee (IACUC no. 121203).

\section{Animals and Diets}

Twelve multiparous cows averaging (mean \pm SD) 703 $\pm 41 \mathrm{~kg}$ of BW, $46.2 \pm 4.1 \mathrm{~kg}$ of milk yield, and $173 \pm$ 37 DIM and 4 primiparous cows averaging $629 \pm 16 \mathrm{~kg}$ of BW, $34 \pm 3.7 \mathrm{~kg}$ of milk yield, and $179 \pm 27$ DIM at the beginning of the study were used. Cows were housed in a tie-stall barn equipped with individual feed tubs. Baseline DMI data were recorded using a Super Data Ranger (American Calan Inc., Northwood, NH) for 2 wk before the beginning of the experiment and averaged (mean $\pm \mathrm{SD}$ ) $24.5 \pm 2.6 \mathrm{~kg} / \mathrm{d}$ during the last $7 \mathrm{~d}$. Body weight was recorded for 3 consecutive days before the beginning of the experiment and averaged (mean \pm SD) $685 \pm 49 \mathrm{~kg}$. Animals were then randomly assigned to 2 groups balanced according to the proportion of DMI relative to BW, which averaged (mean $\pm \mathrm{SD}$ ) 3.94 $\pm 0.35 \%$. Within each group, the following treatments were randomly assigned to cows in a crossover design: (1) ad libitum intake adjusted daily to yield $10 \%$ orts (i.e., AL treatment) or (2) restricted intake set to restrict feed consumption by $10 \%$ of baseline DMI (i.e., RI treatment). Each experimental period lasted $22 \mathrm{~d}$ and consisted of $14 \mathrm{~d}$ for treatments adaptation and 8 d for data and sample collection. 
Diets contained (DM basis) $51.6 \%$ forage as corn silage and grass-legume mix haylage, both grown and harvested during the 2012 growing season, and $48.4 \%$ concentrate mix. Diets were mixed twice daily using a Super Data Ranger (American Calan Inc.) and fed at 0500 and $1400 \mathrm{~h}$. Approximately $40 \%$ of the total daily ration was fed in the morning and the remaining $60 \%$ in the afternoon to account for the difference in feeding time intervals. Orts, if present, were collected and weighed daily before the afternoon feeding using the Super Data Ranger (American Calan Inc.). The ingredients and nutrient composition of the experimental diet are presented in Table 1.

Table 1. Ingredient and nutrient composition of the experimental TMR offered to lactating dairy cows fed for ad libitum or restricted intake $^{1}$

\begin{tabular}{lc}
\hline Item & Value \\
\hline Ingredient composition, \% of diet DM & \\
Corn silage & 40.4 \\
Grass-legume haylage & 11.2 \\
Steam-flaked corn & 3.61 \\
Corn grain, ground, dry & 9.86 \\
Citrus pulp & 7.33 \\
Soybean hulls & 2.93 \\
Molasses & 0.71 \\
Dry distillers grain & 1.07 \\
Soybean meal (48\% CP) & 11.4 \\
Canola meal & 3.50 \\
Urea & 0.18 \\
Minerals and vitamins premix ${ }^{2}$ & 3.30 \\
ProvAAl ELITE & 1.59 \\
BergaFat F100 & \\
Alfalfa pellets & \\
Nutrient composition (DM basis) & 0.81 \\
DM, \% of fresh matter & 2.11 \\
OM, \% of DM & \\
Gross energy, MJ/kg & 43.3 \\
CP, \% of DM & 92.3 \\
NDF, \% of DM & 19.2 \\
ADF, \% of DM & 16.8 \\
NE, Mcal/kg of DM & 34.7 \\
Ca, \% of DM & 24.3 \\
P, \% of DM & 1.60 \\
In vitro true DM digestibility, \% & 0.84 \\
Diet wa fel & 0.37 \\
\hline
\end{tabular}

${ }^{1}$ Diet was fed for ad libitum (adjusted daily to yield $10 \%$ orts) or restricted intake (set to restrict feed consumption by $10 \%$ of baseline DMI).

${ }^{2}$ It provided on an as-fed basis $297 \mathrm{mg} / \mathrm{kg}$ of monensin sodium (Rumensin; Elanco, Greenfield, IN), $11.3 \% \mathrm{Ca}, 1.76 \% \mathrm{P}, 5.98 \% \mathrm{Mg}$, $6 \% \mathrm{~K}, 3 \% \mathrm{~S}, 15 \mathrm{mg} / \mathrm{kg}$ of Co, $650 \mathrm{mg} / \mathrm{kg}$ of Cu; $50 \mathrm{mg} / \mathrm{kg}$ of I, 1,200 $\mathrm{mg} / \mathrm{kg}$ of Mn, $8.97 \mathrm{mg} / \mathrm{kg}$ of Se, $3,700 \mathrm{mg} / \mathrm{kg}$ of $\mathrm{Zn}$, and $87.1 \mathrm{kIU} / \mathrm{kg}$ of vitamin $\mathrm{A}$.

${ }^{3}$ ProvAAl ELITE (Purdue Agribusiness Inc., Salisbury, MD) is a product containing blood meal and Smartamine-M [Rumen-protected DLmethionine (60\% MP-Met); Adisseo, Antony, France].

${ }^{4}$ BergaFat F100 is a product containing palmitic acid (Berg+Schimidt GmbH and Co., Hamburg, Germany).

${ }^{5}$ Alfalfa pellets (guaranteed analysis: $12 \%$ CP, $2 \%$ crude fat, $28 \%$ crude fiber, $0.9 \%$ Ca, and $0.3 \%$ P; Poulin Grain, Newport, VT) used as bait in the portable, automated, open-circuit gas quantification system.

\section{Animal Performance and Milk Sampling and Analyses}

Body weights were measured during 3 consecutive days before the beginning of the study and during the last $3 \mathrm{~d}$ of each data and sampling collection period immediately after the afternoon milking to determine ADG. Body condition scoring was performed by 3 experienced individuals in the first day of the experiment and in the last day of each experimental period according to Wildman et al. (1982).

Cows were milked twice daily at approximately 0500 and $1600 \mathrm{~h}$, and milk yield was recorded at each milking throughout the experiment. Milk samples were collected on d 15, 16, and 17 of each experimental period during 6 consecutive milking events. Milk samples were preserved in tubes containing 2-bromo2-nitropropan-1,3 diol, pooled by cow according to morning and afternoon milk yield, and kept at $4^{\circ} \mathrm{C}$ until shipping for determination of fat, protein, lactose, TS, and MUN by mid-infrared reflectance spectroscopy (Dairy One Cooperative Inc., Ithaca, NY). Concentrations and yields of milk components and MUN were computed as the weighted means from morning and afternoon milk yields using the results of the pooled milk samples. Energy-corrected milk and 4\% FCM were estimated according to Tyrrell and Reid (1965) and the NRC (2001), respectively. Milk efficiency was assessed as the ratio between DMI-M and milk yield, DMI-M and ECM, and DMI-M and 4\% FCM.

\section{Feed Sampling and Analyses}

Samples of TMR were collected weekly and dried in an forced-air oven (VWR Scientific, Radnor, PA) at $55^{\circ} \mathrm{C}$ for $48 \mathrm{~h}$ for adjustments of dietary ingredients on a DM basis. Offered TMR, orts (when available), and individual dietary ingredients were collected daily during the sampling period, pooled to a weekly sample, and kept frozen in a $-20^{\circ} \mathrm{C}$ freezer until analysis. Total mixed ration, alfalfa pellets (Forage Extender; Poulin Grain, Newport, VT), and orts samples were dried in an air-forced oven $\left(55^{\circ} \mathrm{C}\right.$, for $\left.48 \mathrm{~h}\right)$, ground through a $1-\mathrm{mm}$ screen in a Wiley mill (Thomas Scientific, Swedesboro, NJ), and sent for analysis (Dairy One Forage Laboratory, Ithaca, NY). Total mixed ration and orts samples were analyzed for absolute DM (method 930.15; AOAC International, 2006), ash (method 942.05; AOAC International, 2006), total N using a combustion method (Leco TruMac N Macro Determinator; Leco Corp., St. Joseph, MI), NDF (NDF in feeds-filter bag technique for A200 method 6; Ankom Technology, Fairport, NY; solutions as in Van Soest et al., 1991), and ADF [ADF in feeds-filter bag technique 
for A200 method 5; Ankom Technology; solutions as in method 973.18 (AOAC International, 1998)]. Minerals (Ca and P) were analyzed using a Thermo ICAP 6300 inductively coupled plasma radial spectrophotometer after microwave digestion (CEM application notes for acid digestion; CEM, Matthews, NC). In vitro true DM digestibility (IVTDMD) was done for TMR as $30 \mathrm{~h}$ of ruminal digestibility plus $24 \mathrm{~h}$ of enzymatic (ANALAB; Agri-King Inc., Fulton, IL). Samples were placed in F57 Ankom bags and incubated in Daisy II jars (Ankom Technology) with $1.6 \mathrm{~L}$ of phosphate buffer at $6.78 \mathrm{pH}$ and $0.4 \mathrm{~L}$ of ruminal fluid for $30 \mathrm{~h}$. A $6 \mathrm{~N} \mathrm{HCl}$ solution with $10 \%$ pepsin was added to the jars for an additional $24 \mathrm{~h}$ of incubation, and weighting of the remaining residue in each bag. The TMR was additionally analyzed for GE using an IKA C2000 basic calorimeter system (Dairy One Forage Laboratory).

\section{Carbon Emissions Sampling and Analyses}

Emissions of $\mathrm{CH}_{4}$ and $\mathrm{CO}_{2}$ were measured using the GQS. Operating procedures, sampling, and calculations used herein were done as reported previously (Dorich et al., 2015; Huhtanen et al., 2015; Watt et al., 2015). Sampling times started at 0700 and $1900 \mathrm{~h}$ on d 1 of the sampling period with the GQS moved sequentially from cow to cow with at least a 1-min interval between samplings for determination of background gas concentration. Sampling was advanced $2 \mathrm{~h}$ daily to account for diurnal variations in $Q \mathrm{CH}_{4}$ and $Q \mathrm{CO}_{2}$, thus allowing for 16 measurements per cow per period. The total time of $Q^{-C_{4}}$ and $Q \mathrm{CO}_{2}$ measurements was $14 \mathrm{~h}$ and 57 min during the entire experiment with an average of 4 min and $33 \mathrm{~s}$ per individual measurement. Cows were trained with the GQS for $10 \mathrm{~d}$ preceding the beginning of the study. Background concentrations ([BC]) of $\mathrm{CH}_{4}$ and $\mathrm{CO}_{2}$ were calculated by linearly interpolating the $[\mathrm{BC}]$ between starting and ending background points. Data were considered accurate if the $[\mathrm{BC}]$ slope had not significantly changed between background points.

The $\mathrm{CH}_{4}$ sensor was calibrated weekly first by cleaning the sensors from any other gas using $\mathrm{N}_{2}$ and then using a preestablished concentration of $\mathrm{CH}_{4}(1,000$ ppm) injected directly into the sensors. The gas concentration in microliters per liter $([\mathbf{G C}])$ was then calculated from the relative sensor voltage output response compared with the known concentration of gas injected when calibration was performed. At the beginning of each experimental period, the air flux sensor was calibrated gravimetrically using $\mathrm{CO}_{2}$ (prefilled 90-g $\mathrm{CO}_{2}$ cylinders; KEE Action Sports LLC, Sewell, NJ). Carbon dioxide was released for 2 min followed by 2 min without any gas release into the feed trough of the GQS at the same place where the nostril of the animal should be positioned. Five to 6 gas releases were done per calibration to decrease possible within-cylinder variation, thus achieving $99.96 \%$ mean recovery of $\mathrm{CO}_{2}$ with a variation of $3.5 \%$.

Calculations of carbon emissions were completed using the McLean and Tobin (1987) equation adapted from chamber systems and calculated on a per second basis. The volumetric flow rate in liters per minute at any given time $i\left(Q_{\mathrm{C}(i)}\right)$ equals the capture rate of air $\left(\mathrm{C}_{\mathrm{p}}\right)$ times the difference between $[\mathrm{GC}]$ and $[\mathrm{BC}]$ or atmospheric concentration of this gas multiplied by the volumetric air flow $\left(Q_{\text {air }}, \mathrm{L} / \mathrm{min}\right)$ corrected for $1 \mathrm{~atm}$. The capture rate of air was considered to be 1.0 for indoor farm conditions without wind (Huhtanen et al., 2015). The equation is presented below:

$$
Q_{\mathrm{C}(i)}=\mathrm{C}_{\mathrm{p}(i)} \times\left([\mathrm{GC}]_{(i)}-[\mathrm{BC}]_{(i)}\right) \times Q_{\mathrm{air}(i)} \div 10^{6} .[1]
$$

The mass flux of gas $\left(Q_{\mathrm{m}(i)}\right)$ in grams was calculated using the ideal gas law, in which flux $(Q)$ of any given gas (m) at any given time $(i)$ equals $Q_{\mathrm{C}}$ times 273.15 $\mathrm{K}$ divided by the sum of $273.15 \mathrm{~K}$ and air temperature $\left(T_{\text {air }}\right)$ in degrees Celsius multiplied by the gas density ( $\rho ; 0.717$ and $1.977 \mathrm{~g} / \mathrm{L}$ for $\mathrm{CH}_{4}$ and $\mathrm{CO}_{2}$, respectively):

$$
Q_{\mathrm{m}(i)}=Q_{\mathrm{C}(i)} \times 273.15 \div\left(273.15+T_{\operatorname{air}(i)}\right) \times \rho .
$$

The equilibrium time of the $\mathrm{CH}_{4}$ and $\mathrm{CO}_{2}$ concentration measurement was $5 \mathrm{~s}$. Over a 5 -min animal visit, the equilibrium time represented less than $1.5 \%$ of the visit and was disregarded. However, the response of the $\mathrm{CH}_{4}$ and $\mathrm{CO}_{2}$ sensors lags by 4 to $5 \mathrm{~s}$, time necessary for gas to flow from the muzzle of the animal to the sensors in the system. To account for lag time of the $[\mathrm{GC}]$ and $[\mathrm{BC}]$ measurements, they were offset by $5 \mathrm{~s}$, so that real-time sensor information (such as ear-tag readings and head-position data) were synchronized with the concentration sensor data.

\section{Energy Balance and DMI Estimation}

The NRC (2001) model equation for lactating Holstein cows was used to predict DMI-NRC. The prediction formula was as described in the NRC (2001): $"$ DMI-NRC $=(0.372 \times$ fat corrected milk $+0.0968 \times$ body weight $\left.{ }^{0.75}\right) \times\left(1-\mathrm{e}^{[(-0.192) \times(\text { week of lactation }+3.67)]}\right)$." In addition, a second estimation of DMI was added for comparison, using the model of Casper and Mertens (2010): "DMI $(\mathrm{kg} / \mathrm{d})=\left\{821.3+\left[0.27 \times Q^{2} \mathrm{CO}_{2}(\mathrm{~g} / \mathrm{d})\right]\right.$ $+[1.18 \times$ milk yield $(\mathrm{kg} / \mathrm{d})]\} \div 126$ ", which is based on linear relationships between DMI and $\mathrm{QCO}_{2}$ adjusted for milk yield. This model was recently used by the Cornell Net Carbohydrate and Protein System v 6.1 (CNCPS v 6.1; Fox et al., 2004) for estimation of DMI 
and comparison of gaseous emissions from forage-based diets (Higgs et al., 2013; Russomanno et al., 2013) and grazed pasture (Watt et al., 2015).

The DMI-E procedure was based on the net energy system to account for the loss of chemical energy in feces, urine, $\mathrm{CH}_{4}$, and $\mathrm{HP}$ (Moe et al., 1972). Energy loss from $\mathrm{CH}_{4}$ in the rumen was measured by multiplying volumetric $Q \mathrm{CH}_{4}$ by $2.17 \mathrm{MJ} / \mathrm{L}$.

The RQ (i.e., $\mathrm{CO}_{2} \div \mathrm{O}_{2}$ consumption) was used to estimate HP. According to Ferris et al. (1999) and Madsen et al. (2010), RQ ranges from 0.90 to 1.1. A $\mathrm{RQ}$ of 0.95 was used in the current study following Madsen et al. (2010). Heat production was calculated using the equation of Brouwer (1965) modified (i.e., no adjustment for excreted urinary N) by Kaufmann et al. (2011):

$$
\begin{gathered}
\mathrm{HP}(\mathrm{MJ} / \mathrm{d})=[(4.96+16.07 \div \mathrm{RQ}) \\
\left.\times \mathrm{QCO}_{2}(\mathrm{~L} / \mathrm{d})\right] \div 1,000,
\end{gathered}
$$

where $\mathrm{RQ}=0.95$.

Intake of ME was estimated according to the following equation:

$$
\begin{gathered}
\text { ME intake }(\mathrm{MJ} / \mathrm{d})=[\mathrm{HP}(\mathrm{MJ} / \mathrm{d})+\text { milk energy } \\
(\mathrm{MJ} / \mathrm{d})]+ \text { tissue energy balance }(\mathrm{MJ} / \mathrm{d}),
\end{gathered}
$$

where tissue energy balance was calculated according to the empty BW energy needed to vary $1 \mathrm{~kg}$ with an efficiency of 0.85 for weight gain $(31.8 \mathrm{MJ} / \mathrm{kg})$ and 0.82 for weight loss (29.2 MJ/kg; NRC, 2001) according to actual BCS of cows when measurements were taken. Milk-energy output (MJ/d) was calculated according to the NRC (2001): milk energy $(\mathrm{MJ} / \mathrm{d})=\{[0.384 \times$ fat $(\%)]+[0.223 \times$ protein $(\%)]+[0.199 \times$ lactose $(\%)]\}$ $\times$ milk yield $(\mathrm{kg} / \mathrm{d})$.

Digestible energy (DE) intake was estimated as the sum of ME intake and energy emitted as $\mathrm{CH}_{4}$ and excreted as urine:

$$
\begin{gathered}
\text { DE intake }(\mathrm{MJ} / \mathrm{d})=\mathrm{ME} \text { intake }(\mathrm{MJ} / \mathrm{d}) \\
+\mathrm{CH}_{4} \text {-energy output }(\mathrm{MJ} / \mathrm{d}) \\
+ \text { urinary-energy output }(\mathrm{MJ} / \mathrm{d}) .
\end{gathered}
$$

Urinary energy was not measured in the present study, but it was calculated as $6.5 \%$ of estimated ME according to Ferris et al. (1999) and Ferrell and Oltjen (2008).

Gross energy intake was estimated as the sum of DE intake and fecal-energy output as follows:

GE intake estimated $(\mathrm{MJ} / \mathrm{d})=\mathrm{DE}$ intake $(\mathrm{MJ} / \mathrm{d})$

$$
+ \text { fecal-energy output (MJ/d), }
$$

where fecal energy was calculated as [DE intake (MJ/d) $\div$ TMR IVTDMD (\%)] - DE intake (MJ/d).

Dry matter intake was estimated as follows:

$$
\begin{gathered}
\text { DMI-E }=\text { GE intake estimated }(\mathrm{MJ} / \mathrm{d}) \\
\div \text { diet GE concentration }(\mathrm{MJ} / \mathrm{kg}),
\end{gathered}
$$

where diet GE concentration averaged 19.2 and 19.1 $\mathrm{MJ} / \mathrm{kg}$ for sampling periods 1 and 2, respectively.

\section{Statistical and Sensitive Analyses}

All response variables were analyzed using the MIXED procedure of SAS (SAS 9.4; SAS Institute Inc., Cary, NC) and the Fit Model procedure of JMP (JMP Pro 10.0; SAS Institute Inc.). Results are presented as least squares means. The following model was used for milk yield, milk composition, DMI-M, ADG, BCS, $Q \mathrm{CH}_{4}, Q \mathrm{CO}_{2}, Q \mathrm{O}_{2}, \mathrm{DMI}-\mathrm{E}, \mathrm{DMI}-\mathrm{NRC}$, and DMI-CM:

$$
Y_{i j k l}=\mu+S_{i}+P_{j}+C_{k}(S)_{i}+T_{l}+E_{i j k l},
$$

where $Y_{i j k l}$ is the dependent variable, $\mu$ is the overall mean, $S_{i}$ is the effect of sequence $i, P_{j}$ is the effect of period $j, C_{k}(S)_{i}$ is the effect of cow $k$ within sequence $i, T_{l}$ is the effect of treatment $l$, and $E_{i j k l}$ is the overall error. Individual 5-min measurements of $Q^{-C_{4}}$ and $\mathrm{QCO}_{2}$ were averaged in each sampling period to yield 1 measurement per cow. Averaged values were used for carbon flux results, to compare DMI-M and DMI models (i.e., DMI-E, DMI-NRC, and DMI-CM), and for sensitivity analysis. Individual gas 5-min measurements from all animals were used to calculate repeatability (variance of cow within sequence divided by total variance; Huhtanen et al., 2015) and spot measurements standard deviation and coefficient of variation.

The root mean square prediction error (RMSPE) was used to compare the DMI models and was calculated as $\sqrt{ }\left[\Sigma(\text { observed value } i-\text { predicted value } i)^{2} \div\right.$ number of observations] as described by Kohn et al. (1998).

To assess the variation that could modify the estimation of DMI-E, a sensitivity analysis was conducted for HP by varying RQ in 1.05, 1.0, 0.95, 0.90, and 0.85 . Values were chosen according to the range of RQ reported in the literature (Madsen et al., 2010), as well as preliminary values from our laboratory using an $\mathrm{O}_{2}$ electrochemical sensor (Pereira et al., 2015). We also conducted a sensitivity analysis to estimate DMI by reducing the IVDMD by 4,8 , and $12 \%$ from measured $76.1 \%$ value, in which for each multiple of maintenance intake, a digestibility depression of $4 \%$ should be taken into account (NRC, 2001). 
Table 2. Nutrient intake and changes in ADG and BCS in lactating dairy cows fed for ad libitum (AL) or restricted intake $(\mathrm{RI})^{1}$

\begin{tabular}{lcccc}
\hline Item & $\mathrm{AL}$ & $\mathrm{RI}$ & $\mathrm{SEM}$ & Effect $(P>F)^{3}$ \\
\hline $\mathrm{DMI}^{\mathrm{M}}{ }^{2}{ }^{2} \mathrm{~kg} / \mathrm{d}$ & 23.8 & 22.4 & 0.68 & 0.001 \\
$\mathrm{~N}$ intake, $\mathrm{g} / \mathrm{d}$ & 674 & 625 & 18.72 & $<0.001$ \\
$\mathrm{NDF}$ intake, $\mathrm{kg} / \mathrm{d}$ & 7.98 & 7.49 & 0.21 & $<0.001$ \\
$\mathrm{ADF}$ intake, $\mathrm{kg} / \mathrm{d}$ & 5.25 & 4.91 & 0.14 & $<0.001$ \\
OM intake, $\mathrm{kg} / \mathrm{d}$ & 22.2 & 20.6 & 0.62 & $<0.001$ \\
TDN intake, $\mathrm{kg} / \mathrm{d}$ & 16.8 & 15.7 & 0.47 & $<0.001$ \\
Gross energy intake, MJ/d & 456 & 428 & 13.1 & 0.001 \\
ADG, kg/d & 0.41 & -0.36 & 0.16 & 0.002 \\
BCS change, score per period & -0.13 & -0.15 & 0.05 & 0.83 \\
\hline
\end{tabular}

${ }^{1}$ Diet was fed for ad libitum (adjusted daily to yield $10 \%$ orts) or restricted intake (set to restrict feed consumption by $10 \%$ of baseline DMI).

${ }^{2} \mathrm{DMI}-\mathrm{M}=\mathrm{DMI}$ measured.

${ }^{3}$ Probability of treatment effect (AL vs. RI); significance was declared at $P \leq 0.05$ and trends at $0.05<P \leq$ 0.10

\section{RESULTS AND DISCUSSION}

\section{Nutrient Intake and Milk Yield and Composition}

One cow and related data were removed from the statistical and sensitivity analyses because she consistently refused to use the GQS. Intake of nutrients is presented in Table 2. As expected, cows fed for AL had higher DMI-M $(P=0.001 ;$ mean $=23.8 \mathrm{~kg} / \mathrm{d})$ than those fed for RI (mean $=22.4 \mathrm{~kg} / \mathrm{d})$. Increased DMI-M with the AL treatment resulted in increased $(P \leq 0.001)$ intakes of N, NDF, ADF, OM, TDN, and GE.

Milk yield and milk composition results are presented in Table 3. Although DMI-M was highest in cows fed for AL, milk yield did not differ significantly between treatments. Therefore, it appears that mobilization of body reserves was the metabolic strategy used by cows on the RI treatment to maintain milk yield. In fact, cows fed for AL gained weight (mean $\mathrm{ADG}=+0.41$ $\mathrm{kg} / \mathrm{d} ; P=0.002$ ), whereas those fed for RI lost weight (mean ADG $=-0.36 \mathrm{~kg} / \mathrm{d}$; Table 2). Concentrations of milk fat $($ mean $=3.82 \%)$, lactose $($ mean $=4.82 \%)$, and TS $($ mean $=11.8 \%)$ were not affected by treatments, whereas those of milk protein $(P<0.001)$ and milk SNF $(P<0.001)$ were highest in cows fed for AL. Cows fed for AL yielded more milk protein (1.26 vs. 1.18 $\mathrm{kg} / \mathrm{d} ; P=0.001)$ and milk SNF $(3.20$ vs. $3.04 ; P=$ 0.003 ) than those fed for RI as a result of the highest concentrations of milk protein and milk SNF. In addition, cows fed for AL yielded highest milk lactose $(P$ $=0.006)$ and milk TS $(P=0.01)$, which are explained by a numerical increase in milk yield and significant increases in the yields of milk protein and milk lactose, respectively. The concentration of MUN was highest in cows fed for AL (17.1 vs. $15.9 \mathrm{mg} / \mathrm{dL} ; P=0.002)$, and it is partially explained by highest $\mathrm{N}$ intake (674 vs. $625 \mathrm{~g} / \mathrm{d}$; Table 2), which agrees with previous research (Olmos Colmenero and Broderick, 2006). Both ECM and $4 \%$ FCM were highest in cows fed for AL because of higher yields of milk protein $(+0.08 \mathrm{~g} / \mathrm{d} ; P<0.001)$ and milk fat $(+0.08 \mathrm{~g} / \mathrm{d} ; P=0.11)$ compared with cows fed for RI. Feed efficiency, expressed as milk yield/ DMI-M, tended $(P=0.10)$ to be higher in cows fed for RI and did not differ significantly between treatments when expressed as ECM/DMI-M or $4 \%$ FCM/DMI-M (Table 3).

\section{Carbon Fluxes, Dietary Energy Calculations, and DMI Estimation}

Carbon fluxes, dietary energy calculations, GE intake, DMI-E, DMI-NRC, and DMI-CM are presented in Table 4. Treatments did not significantly differ for $Q \mathrm{CH}_{4}$ and $Q \mathrm{CO}_{2}$. Regression of $Q \mathrm{CO}_{2}$ against $Q \mathrm{CH}_{4}$ (Figure 1; $Q \mathrm{CO}_{2}=4,961+18.3 \times Q^{2} \mathrm{CH}_{4}, P<0.001$ ) resulted in an $\mathrm{R}^{2}$ of 0.73 , indicating a strong relationship between these 2 variables, which agrees with previous research (Madsen et al., 2010; Huhtanen et al., 2015). In addition, the repeatability of gas measurements averaged 0.88 and 0.87 for $Q \mathrm{CH}_{4}$ and $Q \mathrm{CO}_{2}$, respectively. Huhtanen et al. (2015) also found high repeatability for $Q \mathrm{CH}_{4}($ mean $=0.75)$ and $Q \mathrm{CO}_{2}($ mean $=0.86)$ in an experiment with 75 lactating dairy cows in a freestall barn with access to a GQS (Swedish experiment) and 118 lactating dairy cows using a robotic milking system fitted with a GQS (United States experiment). In general, the between- and within-cow variability of gaseous data measured was low in the current study. For instance, the spot measurements standard deviation and coefficient of variation for $Q \mathrm{CO}_{2}$ were 1,176 $\mathrm{L} / \mathrm{d}$ and $8.72 \%$, respectively (measured using individual 5 -min spot measurements of all cows). Variation in spot short-term measurements of carbon gases may be reduced by increasing sampling frequency and using the GQS for longer periods, as hypothesized by Hammond et al. (2013) and Dorich et al. (2015). The coefficient of 
variation of $8.72 \%$ observed for $\mathrm{QCO}_{2}(\mathrm{~L} / \mathrm{d})$ resulted in a difference of $\pm 0.28 \mathrm{MJ}$ in the estimations of $\mathrm{HP}$ and in an absolute difference of $6.83 \%$ (or 19.9 to $22.9 \mathrm{~kg} / \mathrm{d}$ ) of DMI-E. Therefore, this variation should be taken into account when using the proposed methodology for assessment of DMI-E.

Heat production, estimated using Equation 3, was not significantly different between treatments and averaged $149 \mathrm{MJ} / \mathrm{d}$ (Table 4). The lack of treatment effect on HP may be explained by the relatively small differences in milk yield, DMI, and ADG across treatments. In addition, cow exercise (i.e., roundtrip from the stall to the milking parlor) was similar and diet composition did not differ for cows fed for AL or RI. According to Brosh et al. (1998), HP is affected by animal metabolic rate, which varies according to milk yield, BW, feed composition, and rate of exercise. Milk-energy output did not differ and averaged $118 \mathrm{MJ} / \mathrm{d}$ across treatments (Table 4). On the other hand, empty BW change was positive $(13.3 \mathrm{MJ} / \mathrm{d} ; P=0.002)$ for cows fed for $\mathrm{AL}$ and negative $(-10.6 \mathrm{MJ} / \mathrm{d})$ for those fed for RI. Intake of ME, calculated using Equation 4, was highest with the AL treatment ( 282 vs. $253 \mathrm{MJ} / \mathrm{d} ; P=0.01$ ) primarily because of positive empty BW change and ADG. Positive ADG results in retention of body energy mostly as protein and fat, and contains $29.2 \mathrm{MJ} / \mathrm{kg}$ of $\mathrm{BW}$, whereas tissue loss releases $31.8 \mathrm{MJ} / \mathrm{kg}$ of $\mathrm{BW}$ as energy available for other body functions (NRC, 2001). The efficiency in which the body uses body tissue as a source of energy is 0.85 for anabolism and 0.82 for catabolism (NRC, 2001).

Intake of $\mathrm{DE}$, estimated by the sum of $\mathrm{ME}$ intake, $\mathrm{CH}_{4}$ energy, and urinary energy (i.e., Equation 5), was highest in cows fed for AL (327 vs. $295 \mathrm{MJ} / \mathrm{d}$; $P=$ 0.01; Table 4). Similarly, GE intake estimated (Equation 6) was highest with the AL treatment (430 vs. 388 $\mathrm{MJ} / \mathrm{d} ; P=0.01$; Table 4). However, mean GE intake estimated (409 MJ/d) was lower than mean GE intake measured (442 MJ/d) by $43 \mathrm{MJ} / \mathrm{d}$. We assumed a RQ of 0.95 to calculate HP in cows fed for AL or RI because previous studies showed that the RQ can vary from 0.9 to 1.1 (Ferris et al., 1999; Madsen et al., 2010). The use of a common RQ to estimate HP may not have captured individual animal variation, explaining, to a certain extent, the underestimation of GE intake in the current study. In addition to the RQ, the sampling schedule used herein (every $2 \mathrm{~h}$ for $8 \mathrm{~d}$ ) may not have being entirely representative of the daily $Q^{-O_{2}}$ bouts, ultimately affecting our estimations of HP.

Using GE intake measurements, DMI-E was calculated using Equation 7 and was highest for cows fed for AL (22.5 vs. $20.2 \mathrm{~kg} / \mathrm{d} ; P=0.01$; Table 4$)$. It is important to note, however, that mean DMI-E across treatments $(21.4 \mathrm{~kg} / \mathrm{d})$ was lower than mean DMI-M $(23.1 \mathrm{~kg} / \mathrm{d})$ by $1.7 \mathrm{~kg} / \mathrm{d}$, and this underestimation was more pronounced with $\mathrm{RI}(-2.11 \mathrm{~kg} / \mathrm{d})$ than $\mathrm{AL}$ $(-1.34 \mathrm{~kg} / \mathrm{d})$. Coupling of $Q \mathrm{CO}_{2}$ and $Q \mathrm{CH}_{4}$ with backward dietary energy partition calculations were used

Table 3. Milk yield, milk composition, and feed efficiency in lactating dairy cows fed for ad libitum (AL) or restricted intake $(\mathrm{RI})^{1}$

\begin{tabular}{lcccc}
\hline Item & AL & RI & SEM & Effect $(P>F)^{2}$ \\
\hline Milk yield, kg/d & 39.7 & 39.1 & 1.58 & 0.29 \\
Milk fat, \% & 3.83 & 3.81 & 0.10 & 0.76 \\
Milk fat, kg/d & 1.53 & 1.45 & 0.06 & 0.11 \\
Milk protein, \% & 3.14 & 3.09 & 0.04 & $<0.001$ \\
Milk protein, kg/d & 1.26 & 1.18 & 0.04 & 0.001 \\
Milk lactose, \% & 4.83 & 4.82 & 0.02 & 0.21 \\
Milk lactose, kg/d & 1.94 & 1.86 & 0.07 & 0.006 \\
Milk TS, \% & 11.8 & 11.7 & 0.13 & 0.32 \\
Milk TS, kg/d & 4.73 & 4.49 & 0.17 & 0.01 \\
Milk SNF, \% & 7.97 & 7.90 & 0.05 & 0.001 \\
Milk SNF, kg/d & 3.20 & 3.04 & 0.12 & 0.003 \\
MUN, mg/dL & 17.1 & 15.9 & 0.42 & 0.002 \\
ECM, ${ }^{3} \mathrm{~kg} / \mathrm{d}$ & 42.1 & 39.9 & 1.50 & 0.03 \\
4\% FCM, $\mathrm{kg} / \mathrm{d}$ & 39.1 & 37.2 & 1.41 & 0.05 \\
Milk yield/DMI measured, $\mathrm{kg} / \mathrm{kg}$ & 1.68 & 1.72 & 0.04 & 0.10 \\
ECM/DMI measured, kg/kg & 1.76 & 1.79 & 0.04 & 0.31 \\
4\% FCM/DMI measured, kg/kg & 1.63 & 1.67 & 0.04 & 0.28 \\
\hline
\end{tabular}

${ }^{1}$ Diet was fed for ad libitum (adjusted daily to yield $10 \%$ orts) or restricted intake (set to restrict feed consumption by $10 \%$ of baseline DMI).

${ }^{2}$ Probability of treatment effect (AL vs. RI); significance was declared at $P \leq 0.05$ and trends at $0.05<P \leq$ 0.10 .

${ }^{3} \operatorname{ECM}(\mathrm{kg} / \mathrm{d})=[0.0752 \times$ milk yield $(\mathrm{kg} / \mathrm{d})]+[12.3 \times$ fat yield $(\mathrm{kg} / \mathrm{d})]+[6.56 \times \mathrm{SNF}(\mathrm{kg} / \mathrm{d})]($ Tyrrell and Reid, 1965).

${ }^{4} 4 \% \mathrm{FCM}=[0.4 \times$ milk yield $(\mathrm{kg} / \mathrm{d})]+[15 \times$ milk fat yield $(\mathrm{kg} / \mathrm{d})](\mathrm{NRC}, 2001)$. 
Table 4. Methane $\left(Q \mathrm{CH}_{4}\right)$ and $\mathrm{CO}_{2}\left(Q \mathrm{CO}_{2}\right)$ fluxes, estimated $\mathrm{O}_{2}$ consumption, and dietary energy estimations in lactating dairy cows fed for ad libitum (AL) or restricted intake $(\mathrm{RI})^{1}$

\begin{tabular}{|c|c|c|c|c|}
\hline Item & $\mathrm{AL}$ & RI & SEM & Effect $(P>F)^{2}$ \\
\hline$Q \mathrm{CH}_{4}, \mathrm{~g} / \mathrm{d}$ & 472 & 458 & 18.0 & 0.16 \\
\hline$Q \mathrm{CO}_{2}, \mathrm{~L} / \mathrm{d}$ & 6,867 & 6,733 & 195 & 0.20 \\
\hline $\mathrm{O}_{2}$ consumption, ${ }^{3} \mathrm{~L} / \mathrm{d}$ & 6,523 & 6,396 & 185 & 0.20 \\
\hline $\mathrm{HP},{ }^{4} \mathrm{MJ} / \mathrm{d}$ & 150 & 147 & 3.34 & 0.08 \\
\hline Milk energy, ${ }^{5} \mathrm{MJ} / \mathrm{d}$ & 119 & 116 & 4.09 & 0.22 \\
\hline Tissue energy balance, ${ }^{6} \mathrm{MJ} / \mathrm{d}$ & 13.3 & -10.6 & 4.91 & 0.002 \\
\hline ME intake, ${ }^{P} \mathrm{MJ} / \mathrm{d}$ & 282 & 253 & 8.21 & 0.01 \\
\hline $\mathrm{CH}_{4}$ energy, ${ }^{8} \mathrm{MJ} / \mathrm{d}$ & 26.2 & 25.5 & 1.00 & 0.15 \\
\hline Urinary energy, ${ }^{9} \mathrm{MJ} / \mathrm{d}$ & 18.3 & 16.4 & 0.53 & 0.01 \\
\hline DE intake, ${ }^{10} \mathrm{MJ} / \mathrm{d}$ & 327 & 295 & 9.39 & 0.01 \\
\hline Fecal energy ${ }^{11}{ }^{\mathrm{MJ}} / \mathrm{d}$ & 104 & 93.0 & 3.25 & 0.02 \\
\hline GE intake estimated, ${ }^{12} \mathrm{MJ} / \mathrm{d}$ & 430 & 388 & 12.6 & 0.01 \\
\hline DMI-M ${ }^{13} \mathrm{~kg} / \mathrm{d}$ & 23.8 & 22.4 & 0.68 & 0.001 \\
\hline DMI-E ${ }^{14} \mathrm{~kg} / \mathrm{d}$ & 22.5 & 20.2 & 0.66 & 0.01 \\
\hline DMI-NRC, ${ }^{15} \mathrm{~kg} / \mathrm{d}$ & 27.5 & 23.9 & 0.56 & $<0.001$ \\
\hline DMI-CM,${ }^{16} \mathrm{~kg} / \mathrm{d}$ & 22.9 & 22.4 & 0.83 & 0.20 \\
\hline
\end{tabular}

${ }^{1}$ Diet was fed for ad libitum (adjusted daily to yield $10 \%$ orts) or restricted intake (set to restrict feed consumption by $10 \%$ of baseline DMI).

${ }^{2}$ Probability of treatment effect (AL vs. RI); significance was declared at $P \leq 0.05$ and trends at $0.05<P \leq$ 0.10 .

${ }^{3} \mathrm{O}_{2}$ consumption was estimated assuming a respiratory quotient of $0.95\left(Q \mathrm{CO}_{2} \div \mathrm{O}_{2}\right.$ consumption $\left.=0.95\right)$ (Madsen et al., 2010).

${ }^{4}$ Heat production $(\mathrm{HP})$ estimated $(\mathrm{MJ} / \mathrm{d})=(4.96+16.07 \div$ respiratory quotient $) \times Q^{2} \mathrm{CO}_{2}(\mathrm{~L} / \mathrm{d}) \div 1,000$ (Kaufmann et al., 2011).

${ }^{5}$ Milk energy $(\mathrm{MJ} / \mathrm{d})=\{[0.384 \times$ fat $(\%)]+[0.223 \times$ protein $(\%)]+[0.199 \times$ lactose $(\%)]\} \times$ milk yield $(\mathrm{kg} / \mathrm{d})$ (NRC, 2001).

${ }^{6}$ Tissue energy balance $=$ empty BW energy needed to vary $1 \mathrm{~kg}$ was calculated according to the NRC (2001) with an efficiency of 0.85 for weight gain and 0.82 for weight loss.

${ }^{7} \mathrm{ME}$ intake $(\mathrm{MJ} / \mathrm{d})=\mathrm{HP}(\mathrm{MJ} / \mathrm{d})+$ milk energy $(\mathrm{MJ} / \mathrm{d})+$ tissue energy balance $(\mathrm{MJ} / \mathrm{d})(\mathrm{NRC}, 2001)$.

${ }^{8} \mathrm{CH}_{4}$ energy $=Q \mathrm{CH}_{4}(\mathrm{~L} / \mathrm{d}) \times 2.17 \mathrm{MJ} / \mathrm{L}$.

${ }^{9}$ Urinary energy $=\mathrm{ME}$ intake $(\mathrm{MJ} / \mathrm{d}) \times 0.065$ (Ferris et al., 1999).

${ }^{10}$ Digestible energy $(\mathrm{DE})$ intake $(\mathrm{MJ} / \mathrm{d})=\mathrm{ME}$ intake $(\mathrm{MJ} / \mathrm{d})+\mathrm{CH}_{4}$ energy $(\mathrm{MJ} / \mathrm{d})+$ urinary energy $(\mathrm{MJ} / \mathrm{d})$.

${ }^{11}$ Fecal energy $(\mathrm{MJ} / \mathrm{d})=[\mathrm{DE}(\mathrm{MJ} / \mathrm{d}) \div$ in vitro true DM digestibility $(\%)]-\mathrm{DE}(\mathrm{MJ} / \mathrm{d})$.

${ }^{12}$ Gross energy (GE) intake estimated $(\mathrm{MJ} / \mathrm{d})=\mathrm{DE}$ intake $(\mathrm{MJ} / \mathrm{d})+$ fecal energy $(\mathrm{MJ} / \mathrm{d})$.

${ }^{13} \mathrm{DMI}-\mathrm{M}=\mathrm{DMI}$ measured.

${ }^{14}$ DMI-E $(\mathrm{kg} / \mathrm{d}$, DMI estimated $)=$ GE intake estimated $(\mathrm{MJ} / \mathrm{d}) \div \operatorname{diet} \mathrm{GE}$ concentration $(\mathrm{MJ} / \mathrm{kg})$.

${ }^{15}$ Actual animal variables (i.e., milk yield and composition, DIM, and BW) were used by the NRC (2001) to predict DMI according to the equation DMI $(\mathrm{kg} / \mathrm{d})=\left\{[0.372 \times \mathrm{FCM}(\mathrm{kg} / \mathrm{d})]+\left[0.0968 \times \mathrm{BW}^{0.75}(\mathrm{~kg})\right]\right\} \times$ $\left\{1-\mathrm{e}^{[-0.192 \times(\text { week of lactation }+3.67)]}\right\}$.

${ }^{16} \mathrm{DMI}-\mathrm{CM}$ (DMI estimated from an empirical gas-based technique): DMI $(\mathrm{kg} / \mathrm{d})=\left\{821.3+\left[0.27 \times Q \mathrm{CO}_{2}\right.\right.$ $(\mathrm{g} / \mathrm{d})]+[1.18 \times$ milk yield $(\mathrm{kg} / \mathrm{d})]\} \div 126$ (Casper and Mertens, 2010$)$.

for DMI-E estimations, and cumulative estimation errors likely contributed for the difference between mean DMI-E and DMI-M. On the other hand, DMI-NRC averaged $25.7 \mathrm{~kg} / \mathrm{d}$ across treatments (Table 4 ), thereby overestimating DMI-M by $2.6 \mathrm{~kg} / \mathrm{d}$. The equation of Casper and Mertens (2010) was also used to estimate DMI, resulting in a mean value of $22.9 \mathrm{~kg} / \mathrm{d}$ for $\mathrm{AL}$ and $22.4 \mathrm{~kg} / \mathrm{d}$ for RI, and thus underestimated DMI-M only by $0.9 \mathrm{~kg} / \mathrm{d}$ for AL treatment, and had the same value for RI $(22.4 \mathrm{~kg} / \mathrm{d})$. This equation has less cumulative errors when compared with backward estimation measurements and uses fewer variables.

Regressions between DMI-M, DMI-E, DMI-NRC, and DMI-CM are presented in Table 5. The regression between DMI-M and DMI-E resulted in moderate $\left(\mathrm{R}^{2}\right.$
$=0.39, \mathrm{RMSPE}=2.88 ; \mathrm{AL}$ cows $)$ and poor $\left(\mathrm{R}^{2}=\right.$ $0.07, \mathrm{RMSPE}=3.47$; RI cows) relationships (Figure 2). Greater values of RMSPE indicate that observed values are less correlated with the predicted model. All regressions had a larger RMSPE for the RI treatment than for the AL counterpart. We identified 3 cows in the AL treatment that, compared with the remaining animals, emitted lower amounts of $\mathrm{CO}_{2}$ (mean $=6,686$ vs. 6,818 $\mathrm{L} / \mathrm{d}$ ) but had higher milk production (mean $=44.0 \mathrm{vs}$. $38.9 \mathrm{~kg} / \mathrm{d}$ ) and DMI-M (mean = 26.7 vs. $22.7 \mathrm{~kg} / \mathrm{d}$ ). Consequently, these animals had HP values lower than expected. When these 3 cows were removed from the data set, the $\mathrm{R}^{2}$ improved to 0.66 (DMI-E $=1.22+0.92$ $\times$ DMI-M; data not shown), which was similar to the $\mathrm{R}^{2}$ between DMI-M and DMI-NRC for the AL treat- 


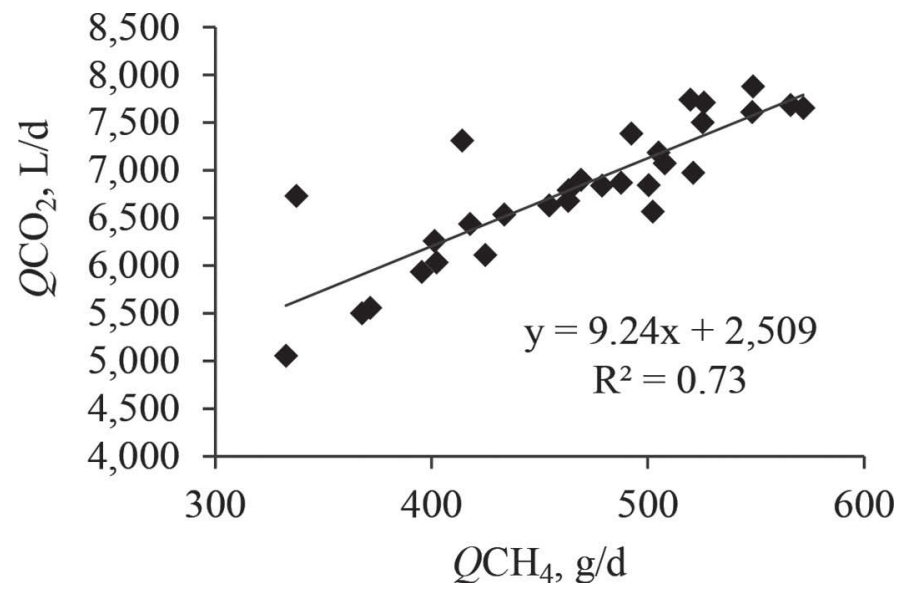

Figure 1. (a) Linear regression between flux of $\mathrm{CO}_{2}\left(Q \mathrm{CO}_{2}\right)$ and flux of $\mathrm{CH}_{4}\left(Q \mathrm{CH}_{4}\right)$ measured by the gas quantification system in lactating dairy cows fed for ad libitum or restricted intake.

ment $\left(\mathrm{R}^{2}=0.66\right.$; Table 5; Figure 2). The difference in $Q \mathrm{CH}_{4}$ between the outlier cows (mean $=478 \pm 18 \mathrm{~g} / \mathrm{d}$ ) and the remaining animals in the same treatment ( 474 $\pm 13 \mathrm{~g} / \mathrm{d}$ ) was very small. In general, higher DMI lead to higher $Q \mathrm{CH}_{4}$ (Hristov et al., 2013; Watt et al., 2015). Therefore, our data appear to indicate that the outlier cows had both lower $Q \mathrm{CH}_{4}$ and $Q \mathrm{CO}_{2}$ than expected, but gross feed conversion efficiency $($ mean $=1.64 \pm$ $0.10)$ was very similar compared with the nonoutlier animals $(1.67 \pm 0.04)$. An alternative explanation is that the 3 highest milk producers may have generated less HP than their counterparts because they were more efficient partitioning feed energy toward milk yield rather than HP (i.e., greater need feed efficiency).

The poor relationship $\left(\mathrm{R}^{2}=0.07\right)$ between DMI-M and DMI-E for cows fed for RI may be related to biased measurements of $\mathrm{QCO}_{2}$ when animals are losing BW. For instance, 10 out of 15 observations for cows fed for $\mathrm{RI}$ resulted in negative ADG, and these animals were likely using body tissues as a source of energy for gluconeogenesis and milk production (Velez and Donkin, 2005). Although the ADG data were sparse, the fact that most ADG values for RI-fed cows were negative resulted in larger differences between DMI-M and DMI$\mathrm{E}$ (Figure 3). The use of body tissue for energy is more efficient than the use of feed for the same metabolic processes (NRC, 2001). As a result, less $\mathrm{O}_{2}$ is consumed

Table 5. Regressions between DMI measured (DMI-M), DMI estimated by backward dietary energy partition calculations (DMI-E), DMI predicted by the NRC (2001; DMI-NRC), and DMI predicted by the Casper and Mertens (2010) equation (DMI-CM) using a data set from lactating dairy cows fed for ad libitum intake (AL) or restricted intake $(\mathrm{RI})^{1}$

\begin{tabular}{|c|c|c|c|c|c|}
\hline Item & $\mathrm{R}^{2}$ & $\mathrm{RMSPE}^{2}$ & Slope & Intercept & $P>F^{3}$ \\
\hline \multicolumn{6}{|l|}{ Regression variable } \\
\hline DMI-M $\times$ DMI-E ${ }^{4} \mathrm{~kg} / \mathrm{kg}$ & 0.28 & 3.19 & 0.54 & 8.97 & 0.002 \\
\hline DMI-NRC $^{5} \times$ DMI-E, $\mathrm{kg} / \mathrm{kg}$ & 0.36 & 6.07 & 0.76 & 0.92 & $<0.001$ \\
\hline DMI-M $\times$ DMI-NRC, $\mathrm{kg} / \mathrm{kg}$ & 0.50 & 4.36 & 0.57 & 13.9 & $<0.001$ \\
\hline DMI-M $\times$ DMI-CM ${ }^{6}{ }^{6} \mathrm{~kg} / \mathrm{kg}$ & 0.30 & 2.81 & 0.60 & 8.74 & $<0.001$ \\
\hline DMI-E $\times$ DMI-CM, kg/kg & 0.49 & 2.60 & 0.76 & 6.34 & $<0.001$ \\
\hline DMI-NRC $\times$ DMI-CM, $\mathrm{kg} / \mathrm{kg}$ & 0.28 & 5.09 & 0.73 & 2.97 & 0.003 \\
\hline \multicolumn{6}{|l|}{ Regression variables by treatment } \\
\hline DMI-M $\times$ DMI-E, $\mathrm{kg} / \mathrm{kg}$ for $\mathrm{AL}$ & 0.39 & 2.88 & 0.62 & 7.53 & 0.01 \\
\hline DMI-M $\times$ DMI-E, $\mathrm{kg} / \mathrm{kg}$ for RI & 0.07 & 3.47 & 0.25 & 14.7 & 0.34 \\
\hline DMI-M $\times$ DMI-NRC, $\mathrm{kg} / \mathrm{kg}$ for $\mathrm{AL}$ & 0.66 & 3.88 & 0.69 & 10.9 & $<0.001$ \\
\hline $\mathrm{DMI}-\mathrm{M} \times \mathrm{DMI}-\mathrm{NRC}, \mathrm{kg} / \mathrm{kg}$ for RI & 0.26 & 4.79 & 0.41 & 17.5 & 0.05 \\
\hline DMI-M $\times$ DMI-CM, $\mathrm{kg} / \mathrm{kg}$ for $\mathrm{AL}$ & 0.29 & 2.91 & 0.58 & 9.17 & 0.03 \\
\hline DMI-M $\times$ DMI-CM, kg $/ \mathrm{kg}$ for RI & 0.31 & 2.72 & 0.69 & 7.04 & 0.03 \\
\hline DMI-E $\times$ DMI-CM, $\mathrm{kg} / \mathrm{kg}$ for AL & 0.56 & 2.08 & 0.79 & 5.19 & 0.001 \\
\hline DMI-E $\times$ DMI-CM, $\mathrm{kg} / \mathrm{kg}$ for RI & 0.51 & 3.03 & 0.96 & 2.86 & 0.003 \\
\hline DMI-NRC $\times$ DMI-E, $\mathrm{kg} / \mathrm{kg}$ for $\mathrm{AL}$ & 0.33 & 5.58 & 0.68 & 3.70 & 0.02 \\
\hline DMI-NRC $\times$ DMI-E, $\mathrm{kg} / \mathrm{kg}$ for RI & 0.34 & 6.53 & 0.69 & 1.97 & 0.02 \\
\hline DMI-NRC $\times$ DMI-CM, $\mathrm{kg} / \mathrm{kg}$ for AL & 0.34 & 5.21 & 0.73 & 2.86 & 0.02 \\
\hline DMI-NRC $\times$ DMI-CM, kg/kg for RI & 0.22 & 4.97 & 0.75 & 2.38 & 0.08 \\
\hline
\end{tabular}

${ }^{1}$ Diet was fed for ad libitum (adjusted daily to yield 10\% orts) or restricted intake (set to restrict feed consumption by $10 \%$ of baseline DMI).

${ }^{2} \mathrm{RMSPE}=$ root mean square predictive error (Kohn et al., 1998).

${ }^{3}$ Probability of treatment effect (AL vs. RI); significance was declared at $P \leq 0.05$ and trends at $0.05<P \leq$ 0.10 .

${ }^{4}$ DMI-E $(\mathrm{kg} / \mathrm{d})=$ gross energy intake estimated $\div$ diet gross energy concentration.

${ }^{5}$ Actual animal variables (i.e., milk yield and composition, DIM, and BW) were used by the NRC (2001) to predict DMI according to the equation DMI $(\mathrm{kg} / \mathrm{d})=\left\{[0.372 \times \mathrm{FCM}(\mathrm{kg} / \mathrm{d})]+\left[0.0968 \times \mathrm{BW}^{0.75}(\mathrm{~kg})\right]\right\} \times$ $\left\{1-\mathrm{e}^{[-0.192 \times(\text { week of lactation }+3.67)}\right\}$.

${ }^{6}$ DMI-CM: DMI $(\mathrm{kg} / \mathrm{d})=\left\{821.3+\left[0.27 \times \mathrm{QCO}_{2}(\mathrm{~g} / \mathrm{d})\right]+[1.18 \times\right.$ milk yield $\left.(\mathrm{kg} / \mathrm{d})]\right\} \div 126($ Casper and Mertens, 2010). 


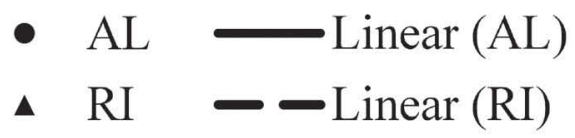

a)
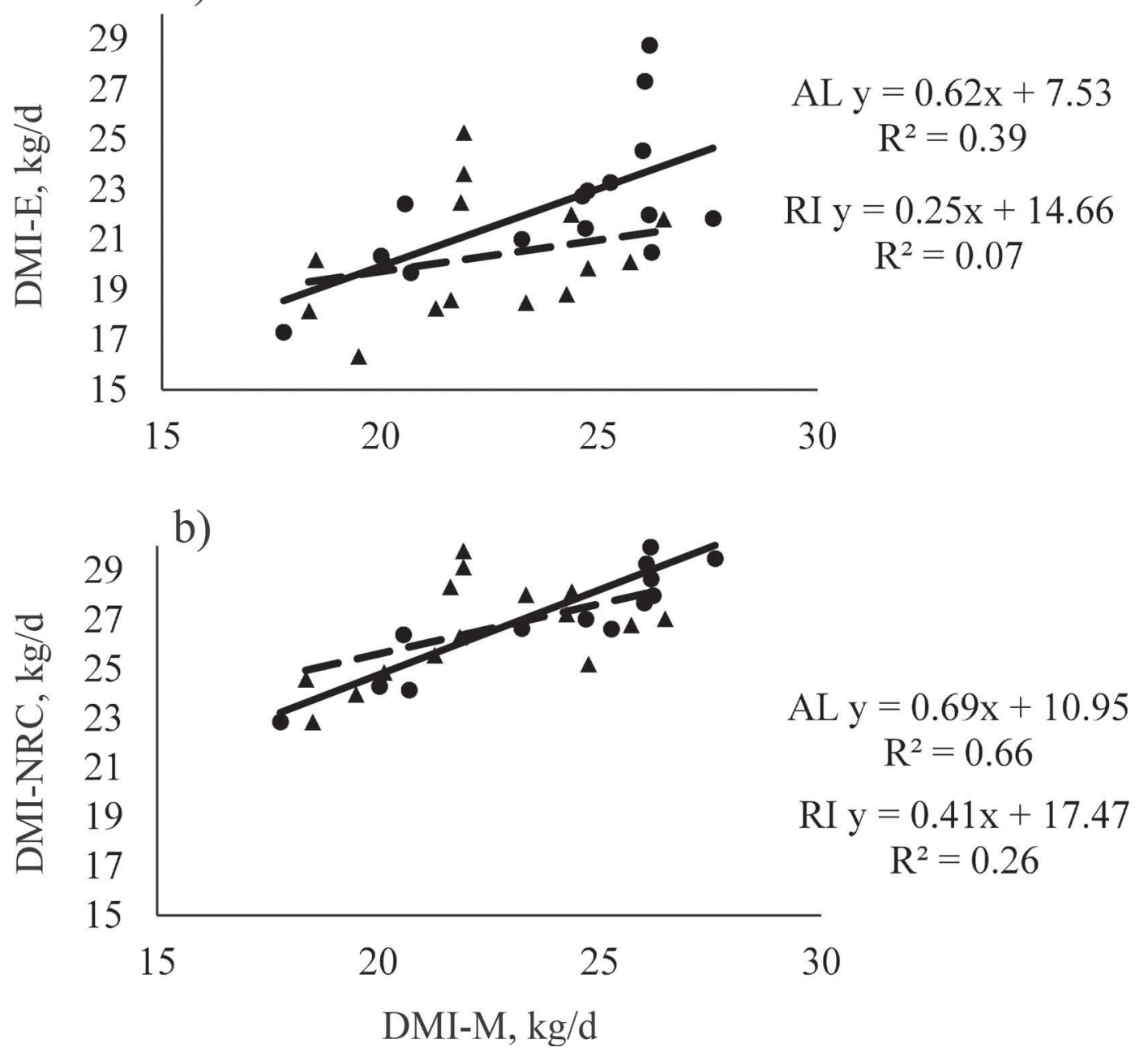

Figure 2. Regressions by treatment $(\mathrm{AL}=$ ad libitum intake and $\mathrm{RI}=$ restricted intake) (a) between DMI measured (DMI-M) and DMI estimated by backward dietary energy partition calculations (DMI-E) and (b) between DMI-M and DMI predicted by the NRC (2001; DMI-NRC). Diets were fed for ad libitum (adjusted daily to yield $10 \%$ orts) or restricted intake (set to restrict feed consumption by $10 \%$ of baseline DMI).

and less heat is produced (Velez and Donkin, 2005). In addition, Sahlu et al. (1988) reported that fasted sheep (negative ADG) had RQ values lower than those fed ad libitum (positive ADG), ultimately resulting in lower than expected $\mathrm{HP}$ due to biased $\mathrm{QCO}_{2}$ measurements. It could also be possible that the baseline period used for feed intake determination was not long enough or that intake demands for individual cows changed during each experimental period of the study. These potential sources of variation may have increased model errors and biased DMI-E values against DMI-M.

The relationship between DMI-M and DMI-CM was relatively low $\left(R^{2}=0.29\right.$ and 0.31 for $A L$ and $R I$, respectively). On the other hand, a better relationship $\left(\mathrm{R}^{2}=0.49\right)$ between DMI-E and DMI-CM was observed, which was expected, as both methodologies rely on $Q^{-O_{2}}$ measurements. It is important to note that the range of DMI-M (17.8 to $27.6 \mathrm{~kg} / \mathrm{d}$, average of $23.1 \mathrm{~kg} / \mathrm{d}$ ) and milk yield (29.0 to $47.8 \mathrm{~kg} / \mathrm{d}$, average of $39.4 \mathrm{~kg} / \mathrm{d}$ ) in our study was narrower when compared with the work from Casper and Mertens (2010; DMI = 3.9 to $29.4 \mathrm{~kg} / \mathrm{d}$, average of $16.3 \mathrm{~kg} / \mathrm{d}$, and milk yield = 5.1 to $56.6 \mathrm{~kg} / \mathrm{d}$, average of $23.3 \mathrm{~kg} / \mathrm{d}$ ). Our experiment was designed to have 2 levels of intake (AL and RI), and this can lead to insufficient variability in the data set to adjust for regressions. A design with wider range 
of DMI could possibly improve regression correlations and our proposed methodology.

\section{Sensitivity Analysis}

Sensitivity analysis results are shown in Table 6 . The analysis showed that DMI-E was closest to DMI-M at $68.1 \%$ IVDMD and RQ values of $0.95,0.90$, and 0.85 , following the percentage differences between data points (Table 6). For instance, cows in the AL treatment with a RQ of 0.95 and IVDMD of $68.1 \%$ and cows in the RI treatment with a RQ of 1.00 and IVDMD of $64.1 \%$ had exactly the same DMI-M and DMI-E averages (RMSPE $=2.25$ and $\mathrm{R}^{2}$ of 0.48 for $\mathrm{AL}$, and $\mathrm{RMSPE}=2.42$ and $\mathrm{R}^{2}$ of 0.43 for $\mathrm{RI}$; data not shown). In the current experiment, DMI-M was between 3 and 4 times the maintenance intake, which could considerably decrease the feed digestibility by 8 to $16 \%$ (NRC, 2001; Huhtanen et al., 2009), thereby validating our sensitivity analysis approach.

\section{CONCLUSIONS}

The methodology proposed herein, which integrated spot short-term measurements of $Q \mathrm{CO}_{2}$ and $Q \mathrm{CH}_{4}$, obtained with a portable, automated, open-circuit gas quantification system (i.e., GreenFeed; C-Lock Inc.), and backward dietary energy partition calculations was able to discriminate differences in DMI between cows fed for $\mathrm{AL}$ or $\mathrm{RI}$ despite the low to moderate rela- tionships between DMI measured and DMI estimated. However, the proposed methodology underestimated DMI, particularly when cows were in negative ADG (i.e., RI treatment). Caution is required when interpreting results from this preliminary, proof-of-concept work because it was assumed constant urinary-energy losses, DM digestibility (done as IVTDMD), and RQ across cows. Variations in RQ among animals can occur as a result of different individual tissue energy balances. Further work should incorporate individual spot shortterm measurements of $\mathrm{O}_{2}$ consumption while including a larger number of animals in the experiments. In addition, further studies should focus on testing different sampling protocols (e.g., number of daily samplings and time of sampling relative to feeding) and length of sampling period (e.g., $>8$ d) to better understand how diurnal variation in enteric carbon emissions affect overall data accuracy and precision.

\section{ACKNOWLEDGMENTS}

Partial funding was provided by the New Hampshire Agricultural Experiment Station (Durham). This is Scientific Contribution Number 2633. This study was also supported by USDA-National Institute of Food and Agriculture (Washington, DC) award (\#201051106-21834) and Hatch Multistate NC-1042 (Project Number NH00616-R; Project Accession Number 1001855). The authors thank the University of New Hampshire (Durham) students Nicole T. Antaya, Kelly

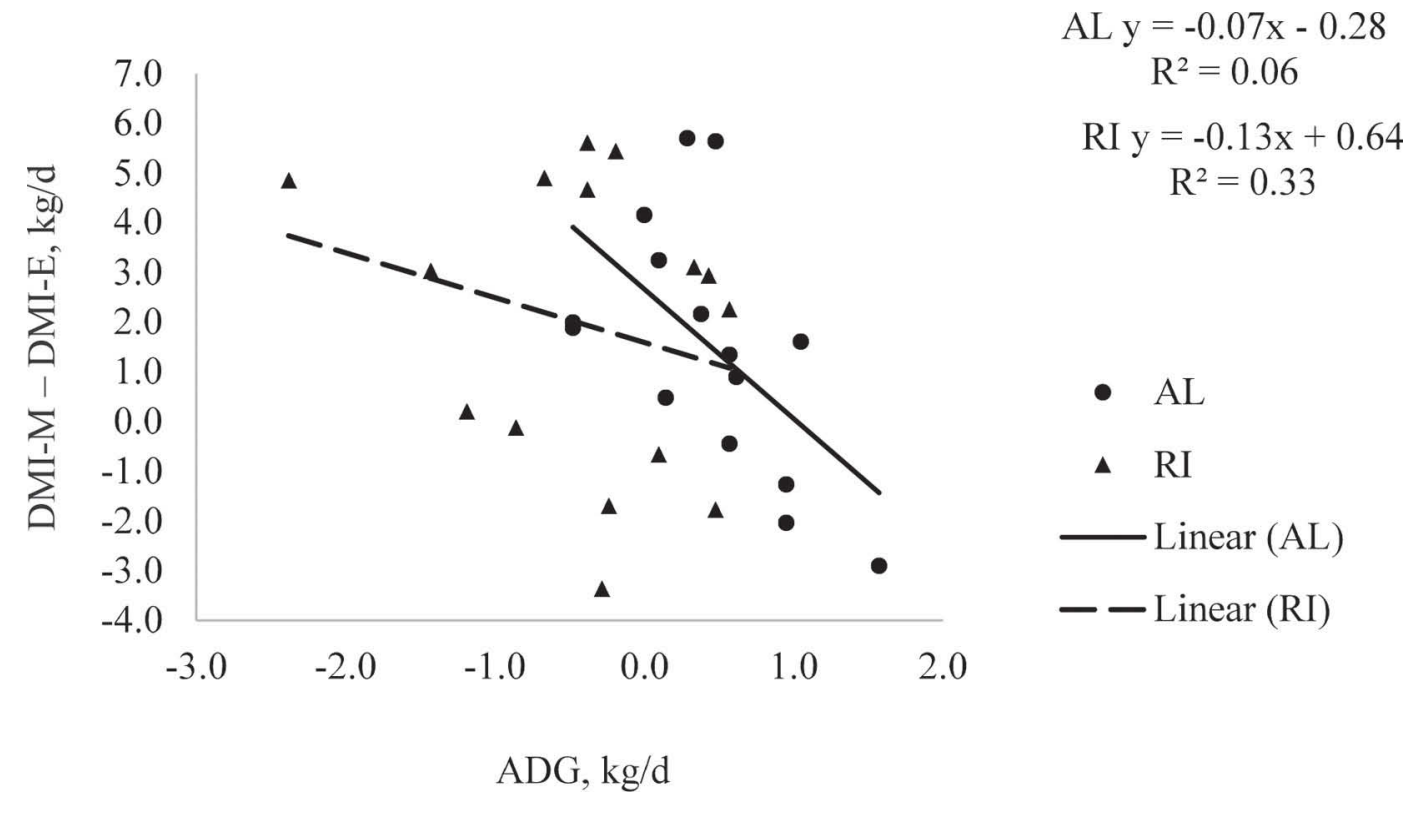

Figure 3. Regressions between ADG and difference between DMI measured (DMI-M) and DMI estimated by backward dietary energy partition calculations (DMI-E). Diets were fed for ad libitum (AL; adjusted daily to yield 10\% orts) or restricted intake (RI; set to restrict feed consumption by $10 \%$ of baseline DMI). 
Table 6. Sensitivity analysis of DMI estimated by backward dietary energy partition calculations (DMI-E) by increasing the respiratory quotient $\left(\mathrm{RQ}=\mathrm{CO}_{2}\right.$ flux $\div \mathrm{O}_{2}$ consumption) from 0.85 to 1.05 and reducing the in vitro true DM digestibility (IVTDMD) by $4 \%$ deductions in lactating dairy cows fed for ad libitum intake $(\mathrm{AL})$ or restricted intake $(\mathrm{RI})^{1}$

\begin{tabular}{|c|c|c|c|c|}
\hline \multicolumn{2}{|c|}{ Fixed variable } & \multirow[b]{2}{*}{ Treatment } & \multirow[b]{2}{*}{ DMI-E } & \multirow{2}{*}{$\begin{array}{c}\% \text { Difference } \\
(\text { DMI measured - DMI-E) }\end{array}$} \\
\hline IVTDMD & $\mathrm{RQ}^{2}$ & & & \\
\hline \multirow[t]{10}{*}{ Measured $(76.1 \%)$} & \multirow[t]{2}{*}{1.05} & $\mathrm{AL}$ & 22.0 & 7.56 \\
\hline & & RI & 19.7 & 12.05 \\
\hline & \multirow[t]{2}{*}{1.00} & $\mathrm{AL}$ & 22.3 & 6.30 \\
\hline & & RI & 20.0 & 10.71 \\
\hline & \multirow[t]{2}{*}{0.95} & $\mathrm{AL}$ & 22.6 & 5.04 \\
\hline & & RI & 20.3 & 9.37 \\
\hline & \multirow[t]{2}{*}{0.90} & $\mathrm{AL}$ & 22.9 & 3.78 \\
\hline & & RI & 20.6 & 8.04 \\
\hline & \multirow{2}{*}{0.85} & $\mathrm{AL}$ & 23.3 & 2.10 \\
\hline & & $\mathrm{RI}$ & 21.0 & 6.25 \\
\hline \multirow[t]{10}{*}{$-4 \%(72.1 \%)$} & \multirow[t]{2}{*}{1.05} & $\mathrm{AL}$ & 22.0 & 7.56 \\
\hline & & RI & 19.7 & 12.05 \\
\hline & \multirow[t]{2}{*}{1.00} & $\mathrm{AL}$ & 22.3 & 6.30 \\
\hline & & RI & 20.0 & 10.71 \\
\hline & \multirow[t]{2}{*}{0.95} & $\mathrm{AL}$ & 22.6 & 5.04 \\
\hline & & RI & 20.3 & 9.37 \\
\hline & \multirow[t]{2}{*}{0.90} & $\mathrm{AL}$ & 22.9 & 3.78 \\
\hline & & RI & 20.6 & 8.04 \\
\hline & \multirow[t]{2}{*}{0.85} & $\mathrm{AL}$ & 23.3 & 2.10 \\
\hline & & RI & 21.0 & 6.25 \\
\hline \multirow{10}{*}{$-8 \%(68.1 \%)$} & \multirow[t]{2}{*}{1.05} & $\mathrm{AL}$ & 23.2 & 2.52 \\
\hline & & RI & 20.8 & 7.14 \\
\hline & \multirow[t]{2}{*}{1.00} & $\mathrm{AL}$ & 23.5 & 1.26 \\
\hline & & RI & 21.1 & 5.80 \\
\hline & \multirow[t]{2}{*}{0.95} & $\mathrm{AL}$ & 23.8 & 0.00 \\
\hline & & RI & 21.4 & 4.46 \\
\hline & \multirow[t]{2}{*}{0.90} & $\mathrm{AL}$ & 24.2 & -1.68 \\
\hline & & RI & 21.7 & 3.13 \\
\hline & \multirow[t]{2}{*}{0.85} & $\mathrm{AL}$ & 24.5 & -2.94 \\
\hline & & RI & 22.1 & 1.34 \\
\hline \multirow[t]{10}{*}{$-12 \%(64.1 \%)$} & \multirow[t]{2}{*}{1.05} & $\mathrm{AL}$ & 24.6 & -3.36 \\
\hline & & RI & 22.1 & 1.34 \\
\hline & \multirow[t]{2}{*}{1.00} & $\mathrm{AL}$ & 24.9 & -4.62 \\
\hline & & RI & 22.4 & 0.00 \\
\hline & \multirow[t]{2}{*}{0.95} & $\mathrm{AL}$ & 25.2 & -5.88 \\
\hline & & RI & 22.7 & -1.34 \\
\hline & 0.90 & $\mathrm{AL}$ & 25.6 & -7.56 \\
\hline & & RI & 23.0 & -2.68 \\
\hline & 0.85 & $\mathrm{AL}$ & 25.9 & -8.82 \\
\hline & & RI & 23.4 & -4.46 \\
\hline
\end{tabular}

${ }^{1}$ Diet was fed for ad libitum (adjusted daily to yield $10 \%$ orts) or restricted intake (set to restrict feed consumption by $10 \%$ of baseline DMI).

${ }^{2}$ Changes in the RQ according to Madsen et al. (2010) and Pereira et al. (2015).

S. O'Connor, Alexandra M. Catalano, Alex Kratzert, and Apryl Perry, as well as the students Milena Lima (Universidade Estadual de Santa Cruz, Ilhéus, Bahia, Brazil) and Daniel Abreu (Universidade Federal de Viçosa, Viçosa, Minas Gerais, Brazil) for supporting data collection and laboratory analyses. The authors also thank Jon Whitehouse and his staff at the University of New Hampshire Fairchild Dairy Teaching and Research Center (Durham) for their assistance with animal care. Gratitude is extended to Patrick Zimmerman and Scott Zimmerman (C-Lock Inc., Rapid City, SD) for their support with the GreenFeed equipment and data analysis.

\section{REFERENCES}

Agricultural and Food Research Council (AFRC). 1993. Energy and Protein Requirements of Ruminants. An advisory manual prepared by the AFRC Technical Committee on Response to Nutrients. CAB Int., Wallingford, UK.

Aharoni, Y., A. Brosh, and E. Kafchuk. 2006. The efficiency of utilization of metabolizable energy for milk production: A comparison of Holstein with F1 Montbeliarde $\times$ Holstein cows. Anim. Sci. $82: 101-109$.

AOAC International. 1998. Official Methods of Analysis. 16th ed. AOAC International, Arlington, VA.

AOAC International. 2006. Official Methods of Analyses. 18th ed. AOAC International, Gaithersburg, MD.

Blaxter, K. L., and J. L. Clapperton. 1965. Prediction of the amount of methane produced by ruminants. Br. J. Nutr. 19:511-522. 
Branco, A. F., F. Giallongo, T. Frederick, H. Weeks, J. Oh, and A. N. Hristov. 2015. Effect of technical cashew nut shell liquid on rumen methane emission and lactation performance of dairy cows. J. Dairy Sci. 98:4030-4040.

Brosh, A., Y. Aharoni, A. A. Degen, D. Wright, and B. Young. 1998. Estimation of energy expenditure from heart rate measurements in cattle maintained under different conditions. J. Anim. Sci. 76:3054-3064.

Brouwer, E. 1965. Report of subcommittee on constant factors. Pages 441-443 in Proc. 3rd Symp. Energy Metab. K. L. Blaxter, ed. Acad. Press, London, UK.

Casper, D. P., and D. R. Mertens. 2010. Carbon dioxide, a greenhouse gas, is sequestered by dairy cattle. J. Dairy Sci. 93(E-Suppl. 1):843-844

Dorich, C. D., R. K. Varner, A. B. D. Pereira, R. Martineau, K. J. Soder, and A. F. Brito. 2015. Short communication: Use of a portable, automated, open-circuit gas quantification system and the sulfur hexafluoride tracer technique for measuring enteric methane emissions in Holstein cows fed ad libitum or restricted. J. Dairy Sci. 98:2676-2681.

Dove, H. 2010. Balancing nutrient supply and nutrient requirements in grazing sheep. Small Rumin. Res. 92:36-40.

Ferrell, C. L., and J. W. Oltjen. 2008. ASAS centennial paper: Net energy systems for beef cattle - Concepts, application, and future models. J. Anim. Sci. 86:2779-2794.

Ferris, C. P., F. J. Gordon, D. C. Patterson, M. G. Porter, and T. Yan. 1999. The effect of genetic merit and concentrate proportion in the diet on nutrient utilization by lactating dairy cows. J. Agric. Sci. 132:483-490.

Fox, D. G., L. O. Tedeschi, T. P. Tylutki, J. B. Russell, M. E. Van Amburgh, L. E. Chase, A. N. Pell, and T. R. Overton. 2004. The Cornell Net Carbohydrate and Protein System model for evaluating herd nutrition and nutrient excretion. Anim. Feed Sci. Technol. 112:29-78.

Hammond, K. J., D. J. Humphries, L. A. Crompton, P. Kirton, C. Green, and C. K. Reynolds. 2013. Methane emissions from growing dairy heifers estimated using an automated head chamber (GreenFeed) compared to respiration chambers or $\mathrm{SF}_{6}$ techniques. Adv. Anim. Sci. 4:391.

Hegarty, R. S. 2013. Applicability of short-term emission measurements for on-farm quantification of enteric methane. Animal $7: 401-408$.

Higgs, R. J., K. L. Russomanno, T. F. Christoph, and M. E. Van Amburgh. 2013. Predicting methane and carbon dioxide emissions using the CNCPS. J. Dairy Sci. 96(E-Suppl. 1):598.

Hristov, A. N., J. Oh, J. L. Firkins, J. Dijkstra, E. Kebreab, G. Waghorn, H. P. S. Makkar, A. T. Adesogan, W. Yang, C. Lee, P. J. Gerber, B. Henderson, and J. M. Tricarico. 2013. Special topicsMitigation of methane and nitrous oxide emissions from animal operations: I. A review of enteric methane mitigation options. J. Anim. Sci. 91:5045-5069.

Huhtanen, P., E. H. Cabezas-Garcia, S. Utsumi, and S. Zimmerman. 2015. Comparison of methods to determine methane emissions from dairy cows in farm conditions. J. Dairy Sci. 98:3394-3409.

Huhtanen, P., M. Rinne, and J. Nousiainen. 2009. A meta-analysis of feed digestion in dairy cows. 2. The effects of feeding level and diet composition on digestibility. J. Dairy Sci. 92:5031-5042.

Junghans, P., J. Voigt, W. Jentsch, C. C. Metges, and M. Derno. 2007. The ${ }^{13} \mathrm{C}$ bicarbonate dilution technique to determine energy expenditure in young bulls validated by indirect calorimetry. Livest. Sci. 110:280-287.

Kaufmann, L. D., A. Münger, M. Rérat, P. Junghans, S. Görs, C. C. Metges, and F. Dohme-Meier. 2011. Energy expenditure of grazing cows and cows fed grass indoors as determined by the ${ }^{13} \mathrm{C}$ bicarbonate dilution technique using an automatic blood sampling system. J. Dairy Sci. 94:1989-2000.

Kohn, R. A., K. F. Kalscheur, and M. Hanigan. 1998. Evaluation of models for balancing the protein requirements of dairy cows. J. Dairy Sci. 81:3402-3414.
Madsen, J., B. S. Bjerg, T. Hvelplund, M. R. Weisbjerg, and P. Lund. 2010. Methane and carbon dioxide ratio in excreted air for quantification of the methane production from ruminants. Livest. Sci. 129:223-227.

Malossini, F., S. Bovolenta, E. Piasentier, C. Piras, and F. Martillotti. 1996. Comparison of $n$-alkanes and chromium oxide methods for estimating herbage intake by grazing dairy cows. Anim. Feed Sci. Technol. 61:155-165.

Mayes, R. W., and H. Dove. 2000. Measurement of dietary nutrient intake in free-ranging mammalian herbivores. Nutr. Res. Rev. 13:107-138.

McLean, J. A., and G. Tobin. 1987. Animal and Human Calorimetry. Cambridge Univ. Press, New York, NY.

Moe, P. W., W. P. Flatt, and H. F. Tyrell. 1972. Net energy value of feeds for lactation. J. Dairy Sci. 55:945-958.

NRC. 2001. Nutrient Requirements of Dairy Cattle. 7th rev. ed. Natl. Acad. Sci., Washington, DC.

Olmos Colmenero, J. J. O., and G. A. Broderick. 2006. Effect of dietary crude protein concentration on milk production and nitrogen utilization in lactating dairy cows. J. Dairy Sci. 89:1704-1712.

Pereira, A. B. D., A. F. Brito, S. A. Utsumi, B. J. Isenberg, and K. S. O'Connor. 2015. Evaluating carbon and oxygen flux variability and heat production in dairy cows using a portable automated gas quantification system. J. Dairy Sci. 98(E-Suppl. 2):610.

Russomanno, K. L., T. F. Christoph, R. J. Higgs, and M. E. Van Amburgh. 2013. Utilization of byproducts from human food production as feedstuffs for dairy cattle and relationship to greenhouse gas emissions and environmental efficiency. J. Dairy Sci. 96(ESuppl. 1):35.

Sahlu, T., H. G. Jung, J. A. Nienaber, and J. G. Morris. 1988. Development and validation of a prediction equation estimating heat production by carbon dioxide entry rate technique. J. Anim. Sci. 66:2036-2043.

Sankhyan, S. K., A. K. Shinde, R. Bhatta, and S. A. Karim. 1999 Comparison of diet and faecal collection methods for assessment of seasonal variation in dry matter intake by sheep maintained on a Cenchrus ciliaris pasture. Anim. Feed Sci. Technol. 82:261-269.

Stewart, A. A., M. Undi, C. Wilson, K. H. Ominski, and K. M. Wittenberg. 2008. Estimation of carbon dioxide production and energy expenditure of grazing cattle by the sulfur hexafluoride $\left(\mathrm{SF}_{6}\right)$ tracer gas technique. Can. J. Anim. Sci. 88:651-658.

Storeheier, P. V., S. D. Mathiesen, and M. A. Sundset. 2003. Estimating faecal output in reindeer during winter. Livest. Prod. Sci. $84: 23-30$

Tylutki, T. P., D. G. Fox, V. M. Durbal, L. O. Tedeschi, J. B. Russell, M. E. Van Amburgh, T. R. Overton, L. E. Chase, and A. N. Pell. 2008. Cornell Net Carbohydrate and Protein System: A model for precision feeding of dairy cattle. Anim. Feed Sci. Technol. 143:174-202.

Tyrrell, H. F., and J. T. Reid. 1965. Prediction of the energy value of cow's milk. J. Dairy Sci. 48:1215-1223.

Van Soest, P. J., J. B. Robertson, and B. A. Lewis. 1991. Methods for dietary fiber, neutral detergent fiber, and nonstarch polysaccharides in relation to animal nutrition. J. Dairy Sci. 74:3583-3597.

Velez, J. C., and S. S. Donkin. 2005. Feed restriction induces pyruvate carboxylase but not phosphoenolpyruvate carboxykinase in dairy cows. J. Dairy Sci. 88:2938-2948.

Watt, L., C. Cameron, G. Krebs, C. Pretzel, S. Nielsen, and S. A. Utsumi. 2015. Differential rumination, intake, and enteric methane production of dairy cows in a pasture-based automatic milking system. J. Dairy Sci. 98:7248-7263. http://dx.doi.org/10.3168/ jds.2015-9463.

Wildman, E. E., G. M. Jones, P. E. Wagner, R. L. Boman, H. F. Troutt Jr., and T. N. Lesch. 1982. A dairy cow body condition scoring system and its relationship to selected production characteristics. J. Dairy Sci. 65:495-501. 